Acta vet. scand. $1972,13,242-250$.

From the Department of Medicine II, Royal Veterinary College, Stockholm, Sweden.

\title{
THE EFFECTS OF ESTROGEN AND PROGESTERONE ON THE BLOOD LEVELS OF GLUCOSE, NON-ESTERIFIED FATTY ACIDS AND CHOLESTEROL IN OVARIECTOMIZED SHEEP
}

By

J. Luthman, G. Jonson and S.-O. Jacobsson

\begin{abstract}
LUTHMAN, J., G. JONSON and S.-O. JACOBSSON: The effects of estrogen and progesterone on the blood levels of glucose, non-esterified fatty acids and cholesterol in ovariectomized sheep. Acta vet. scand. 1972, 13. - The effects of estradiol benzoate and progesterone on blood glucose, NEFA and cholesterol were studied in ovariectomized sheep. Intramuscular injection of $2.5 \mathrm{mg}$ estradiol benzoate gave biphasic changes in NEFA. After 2 hrs. NEFA was decreased, but thereafter an increase occurred and maximum levels were reached after 24 hrs. Blood glucose was significantly increased from 12 to 48 hrs. after the injection. Serum cholesterol was lowered after $24 \mathrm{hrs}$., but thereafter the level increased. Maximum values were obtained after 120 hrs. Progesterone at the same dose did not change any of the measured parameters. Simultaneous administration of estradiol benzoate and progesterone gave similar responses as estradiol benzoate alone.

Blood glucose and NEFA were followed during heat in a lactating cow. Both parameters increased after ovulation.

Since NEFA was increased during so long time after the injection of estradiol benzoate, the mechanism behind this effect was discussed. No lipolytic hormone has been reported to give a response of this duration. Estrogen is known to increase plasma $\mathrm{GH}$, and since $\mathrm{GH}$ is strongly lipolytic in sheep it seemed possible that the elevated NEFA levels were caused by increased GH secretion. There is now evidence that also estrogen-induced changes in serum cholesterol are pituitary dependant. It was therefore considered possible that all the noted metabolic changes were mediated by the pituitary.
\end{abstract}

estrogen; progesterone; blood glucose; non-esterified fatty acids; cholesterol. 
The ability of estrogens to change the blood lipoprotein pattern has been known for several years. A comprehensive study on this topic was published by Furman et al. (1958). Very little, however, is published about the effects of estrogen on the plasma concentration of non-esterified fatty acids (NEFA). Laron \& Kowadlo-Silbergeld (1965) reported that large doses of estradiol benzoate increased plasma NEFA in fasted rats. The metabolic effects of estrogens in adipose tissue was studied in vitro by Gilmour \& McKerns (1966), who found that estrogen stimulated lipid synthesis from glucose. This insulin-like effect was only seen in adipose tissue from female rats. Progesterone, however, did not affect lipid synthesis.

The regulation of lipolysis in adipose tissue is of interest, not only because NEFA is an important metabolic fuel, but also because of the fact that changes in NEFA during certain conditions are also followed by changes in other blood lipid fractions, especially the triglycerides (Carlson et al. 1968). Since the lipolytic effects of most other hormones have been intensely studied and very little information is available on estrogen and progesterone, is was considered to be of interest to study the effects of estrogen and progesterone on plasma NEFA.

This report deals with the effects of estradiol benzoate and progesterone on blood glucose, NEFA and total serum cholesterol in ovariectomized sheep.

\section{MATERIAL AND METHODS}

Ten female lambs at an age of about six months were taken from pasture and ovariectomized. The animals were then kept indoors and fed hay and grain twice daily. The experiments started about four months after surgery. At this time the animals weighed between 30 and $40 \mathrm{~kg}$. The feeding regimens were not changed during the experimental periods.

The hormone preparations used were estradiol benzoate (Ovex B, AB Leo, Hälsingborg, Sweden) and progesterone (Progesterone, ACO, Stockholm, Sweden). The vehicle in both these preparations was arachidoic oil.

The same animals were used throughout the whole study. In a control experiment all animals were given $1 \mathrm{ml}$ arachidoic oil i.m. The effects of $2.5 \mathrm{mg}$ estradiol i.m. were studied in seven animals. One animal was used twice, estradiol was thus given 
at eight occasions. Progesterone was used at the same dosage in five animals. Also in this experiment one animal was used twice. The effects of simultaneous administration of $2.5 \mathrm{mg}$ estradiol and $2.5 \mathrm{mg}$ progesterone were studied in four animals. Blood glucose and NEFA were determined before and 2, 8, 12, 24, 48, 72, and $120 \mathrm{hrs}$. after the injection. Total serum cholesterol was determined before and after 24, 48, 72, and $120 \mathrm{hrs}$. After each experiment the animals had a recovery period of about five weeks.

A lactating cow was studied during a heat period. The first blood sample was taken two days before signs of heat appeared. The time of ovulation was determined by rectal examination and blood was then sampled at varying intervals.

Blood glucose was analyzed according to the glucose oxidase method by means of commercial reagents (Glox, AB Kabi, Stockholm, Sweden) and NEFA according to Dole (1956). Cholesterol was determined by the Liebermann-Burchard reaction without foregoing precipitation of serum proteins ${ }^{\star}$.

\section{RESULTS}

The changes in NEFA, blood glucose and cholesterol after estradiol and progesterone administration are shown in Table 1. Estradiol caused a decrease in NEFA after 2 hrs., but thereafter the level increased and reached a maximum after $24 \mathrm{hrs}$. and then declined slowly. When the changes from the pretreatment levels were compared with corresponding changes in the same animals when used as controls, it was found that NEFA was significantly lowered after $2 \mathrm{hrs} .(\mathrm{P}<0.005)$ and significantly increased after $12(0.01>P>0.005), 24(P<0.005)$ and $48 \mathrm{hrs}$. $(0.01>\mathrm{P}>0.005)$.

The mean cholesterol value in the ovariectomized group was $67 \pm 10 \mathrm{mg} / 100 \mathrm{ml}$ four months after surgery; the mean in a group of five intact female sheep of the same age and kept on the same feeding regimens was $80 \pm 19 \mathrm{mg} / 100 \mathrm{ml}$. The difference was not statistically significant $(P>0.05)$. Also cholesterol showed a biphasic curve after estradiol administration. When the changes from the pretreatment levels were compared as for NEFA, a significant decrease occurred after $24 \mathrm{hrs}$. $(0.05>\mathrm{P}>$

* Cholesterol analysis was performed at the Department of Clinical Biochemistry, Royal Veterinary College. 
T a ble 1. The effects of i.m. injection of estrogen and progesterone on blood glucose, cholesterol and NEFA. Mean $\pm s$.

\begin{tabular}{|c|c|c|c|c|c|c|c|c|}
\hline & \multicolumn{8}{|c|}{ Hours } \\
\hline & $\mathbf{0}$ & 2 & 8 & 12 & 24 & 48 & 72 & 120 \\
\hline & \multicolumn{8}{|c|}{ Glucose $(\mathrm{mg} / 100 \mathrm{ml})$} \\
\hline $\begin{array}{l}\text { Controls } \\
(n=10)\end{array}$ & $\begin{array}{r}40 \\
\pm 2\end{array}$ & $\begin{array}{r}41 \\
\pm 2\end{array}$ & $\begin{array}{r}42 \\
\pm 3\end{array}$ & $\begin{array}{r}41 \\
\pm 2\end{array}$ & $\begin{array}{r}41 \\
\pm 3\end{array}$ & $\begin{array}{r}42 \\
\pm 2\end{array}$ & $\begin{array}{r}41 \\
\pm 3\end{array}$ & $\begin{array}{r}42 \\
\pm 2\end{array}$ \\
\hline $\begin{array}{l}\text { Estradiol } \\
\text { benzoate } \\
(n=8)\end{array}$ & $\begin{array}{r}43 \\
\pm 5\end{array}$ & $\begin{array}{r}45 \\
\pm 6\end{array}$ & $\begin{array}{r}49 \\
\pm 7\end{array}$ & $\begin{array}{r}49 \\
\pm 8\end{array}$ & $\begin{array}{r}50 \\
\pm 5\end{array}$ & $\begin{array}{r}49 \\
\pm 6\end{array}$ & $\begin{array}{r}46 \\
\pm 3\end{array}$ & $\begin{array}{r}46 \\
\pm 6\end{array}$ \\
\hline $\begin{array}{l}\text { Progesterone } \\
(\mathrm{n}=6)\end{array}$ & $\begin{array}{r}42 \\
\pm 3\end{array}$ & $\begin{array}{r}44 \\
\pm 3\end{array}$ & $\begin{array}{r}43 \\
\pm 3\end{array}$ & $\begin{array}{r}43 \\
\pm 2\end{array}$ & $\begin{array}{r}41 \\
\pm 3\end{array}$ & $\begin{array}{r}41 \\
\pm 2\end{array}$ & $\begin{array}{r}43 \\
\pm 3\end{array}$ & \\
\hline \multirow[t]{2}{*}{$\begin{array}{l}\text { Estradiol } \\
\text { benzoate }+ \\
\text { progesterone } \\
(n=4)\end{array}$} & $\begin{array}{r}44 \\
\pm 4\end{array}$ & $\begin{array}{r}44 \\
\pm 5\end{array}$ & $\begin{array}{r}48 \\
\pm 3\end{array}$ & $\begin{array}{r}49 \\
\pm 5\end{array}$ & $\begin{array}{r}48 \\
\pm 1\end{array}$ & $\begin{array}{r}44 \\
\pm 2\end{array}$ & & \\
\hline & \multicolumn{8}{|c|}{ NEFA (meq./1) } \\
\hline Controls & $\begin{array}{r}0.24 \\
\pm 0.04\end{array}$ & $\begin{array}{r}0.25 \\
\pm 0.03\end{array}$ & $\begin{array}{r}0.25 \\
\pm 0.04\end{array}$ & $\begin{array}{r}0.25 \\
\pm 0.03\end{array}$ & $\begin{array}{r}0.26 \\
\pm 0.03\end{array}$ & $\begin{array}{r}0.27 \\
\pm 0.03\end{array}$ & $\begin{array}{r}0.27 \\
\pm 0.03\end{array}$ & $\begin{array}{r}0.26 \\
\pm 0.04\end{array}$ \\
\hline $\begin{array}{l}\text { Estradiol } \\
\text { benzoate }\end{array}$ & $\begin{array}{r}0.27 \\
\pm 0.04\end{array}$ & $\begin{array}{r}0.20 \\
\pm 0.06\end{array}$ & $\begin{array}{r}0.36 \\
\pm 0.15\end{array}$ & $\begin{array}{r}0.46 \\
\pm 0.14\end{array}$ & $\begin{array}{r}0.68 \\
\pm 0.17\end{array}$ & $\begin{array}{r}0.63 \\
\pm 0.27\end{array}$ & $\begin{array}{r}0.58 \\
\pm 0.35\end{array}$ & $\begin{array}{r}0.34 \\
\pm 0.05\end{array}$ \\
\hline Progesterone & $\begin{array}{r}0.25 \\
\pm 0.04\end{array}$ & $\begin{array}{r}0.24 \\
\pm 0.04\end{array}$ & $\begin{array}{r}0.25 \\
\pm 0.04\end{array}$ & $\begin{array}{r}0.27 \\
\pm 0.04\end{array}$ & $\begin{array}{r}0.27 \\
\pm 0.05\end{array}$ & $\begin{array}{r}0.26 \\
\pm 0.04\end{array}$ & $\begin{array}{r}0.25 \\
\pm 0.02\end{array}$ & \\
\hline $\begin{array}{l}\text { Estradiol } \\
\text { benzoate }+ \\
\text { progesterone }\end{array}$ & $\begin{array}{r}0.28 \\
\pm 0.03\end{array}$ & $\begin{array}{r}0.20 \\
\pm 0.05\end{array}$ & $\begin{array}{r}0.34 \\
\pm 0.04\end{array}$ & $\begin{array}{r}0.58 \\
\pm 0.09\end{array}$ & $\begin{array}{r}0.76 \\
\pm 0.12\end{array}$ & $\begin{array}{r}0.91 \\
\pm 0.28\end{array}$ & & \\
\hline & \multicolumn{8}{|c|}{ Cholesterol $(\mathrm{mg} / 100 \mathrm{ml})$} \\
\hline Controls & $\begin{array}{r}85 \\
\pm 17\end{array}$ & & & & $\begin{array}{r}99 \\
\pm 21\end{array}$ & $\begin{array}{r}1.03 \\
\pm 34\end{array}$ & $\begin{array}{r}86 \\
\pm 18\end{array}$ & $\begin{array}{r}83 \\
\pm 12\end{array}$ \\
\hline $\begin{array}{l}\text { Estradiol } \\
\text { benzoate }\end{array}$ & $\begin{array}{r}89 \\
\pm 30\end{array}$ & & & & $\begin{array}{r}63 \\
\pm 20\end{array}$ & $\begin{array}{r}99 \\
\pm 13\end{array}$ & $\begin{array}{r}108 \\
\pm 28\end{array}$ & $\begin{array}{r}112 \\
\pm 17\end{array}$ \\
\hline Progesterone & $\begin{array}{r}108 \\
\pm 18\end{array}$ & & & & $\begin{array}{r}109 \\
\pm 15\end{array}$ & $\begin{array}{r}102 \\
\pm 32\end{array}$ & $\begin{array}{r}107 \\
\pm 14\end{array}$ & $\begin{array}{r}102 \\
\pm 13\end{array}$ \\
\hline $\begin{array}{l}\text { Estradiol } \\
\text { benzoate }+ \\
\text { progesterone }\end{array}$ & $\begin{array}{r}107 \\
\pm 21\end{array}$ & & & & $\begin{array}{r}83 \\
\pm 8\end{array}$ & $\begin{array}{r}98 \\
\pm 13\end{array}$ & $\begin{array}{r}136 \\
\pm 8\end{array}$ & $\begin{array}{r}169 \\
\pm 34\end{array}$ \\
\hline
\end{tabular}


0.01 ), the level steadily increased and after $120 \mathrm{hrs}$. the increase differed significantly from the controls $(0.05>P>0.01)$.

Estradiol also increased blood glucose, the highest values occurred after $24 \mathrm{hrs}$. The changes differed from the controls at $12(0.05>\mathrm{P}>0.01), 24(\mathrm{P}<0.005)$ and $48 \mathrm{hrs} . \quad(0.01>\mathrm{P}$ $>0.005)$.

Progesterone did not change any of the parameters.

The simultaneous administration of estradiol and progesterone gave similar responses as did estradiol alone.

In the cow NEFA decreased immediately before ovulation and increased thereafter. The highest NEFA values occurred about $24 \mathrm{hrs}$. after signs of heat appeared. NEFA then declined and had returned to the preheat level four days after heat. Also blood glucose increased during heat (Fig. 1).

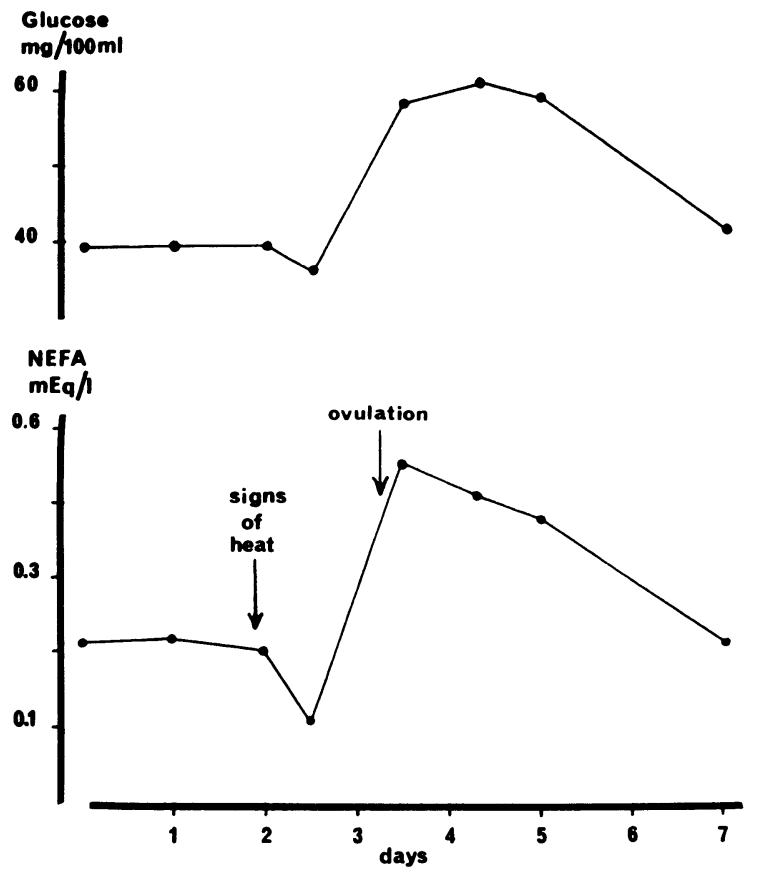

Figure 1. Change in blood glucose and NEFA during heat in a lactating cow.

\section{DISCUSSION}

The greatest changes after estradiol administration occurred in NEFA and cholesterol. NEFA remained elevated for more than 48 hrs. Changes of this duration do not seem to occur after 
administration of any lipolytic hormone. The most prolonged effect has been obtained after growth hormone (GH) administration (Radloff \& Schultz, 1966). Manns \& Boda (1965) reported that the highest NEFA levels occurred $10 \mathrm{hrs}$. after i.v. injection of GH. Nothing is known about the lipolytic effect of estrogen and the question arises if the observed changes were caused by a direct effect of estradiol or were mediated by other endocrine organs.

The ability of estrogen to increase plasma GH is well known. Frantz \& Rabkin (1965) noted that plasma GH was higher in women than in men. Further studies showed that there was no sex difference when the studied subjects were in a state of complete rest, but during any kind of activity the sex difference appeared. The same observations were made in estrogen treated men. The authors suggested that estrogen made the adenohypophysis more sensible to the normal physiological stimuli for $\mathbf{G H}$ release. Plasma GH was also followed in women during the menstrual cycle. A manyfold increase occurred at the time of ovulation. It was suggested several years ago that the growth promoting effect of estrogen might be due to increased GH release (Preston \& Burroughs 1958, Shroder \& Hansard 1958). This hypothesis now seems to be proved, since Trenkle (1970) reported significantly elevated GH levels in diethylstilbestrol fed cattle.

Since GH is lipolytic in sheep (Radloff \& Schultz; Manns \& Boda) it is possible that the increase in NEFA seen in the present study was caused by increased GH secretion. The decline in NEFA observed after 2 hrs. could possibly be the result of a direct effect of estradiol on adipose tissue. As was discussed in the introduction, Gilmour \& McKerns (1966) obtained an insulinlike effect of estrogen on lipid synthesis in female adipose tissue.

The NEFA curve obtained in the cow during heat (Fig. 1) was similar to the GH curves reported by Frantz \& Rabkin after ovulation in women. The role of increased excitement and concomitant catecholamine release, however, can not be excluded.

Davies et al. (1970) found no changes in NEFA after oral administration of diethylstilbestrol to sheep. The difference in NEFA response from the present study may perhaps be explained by different animal material. Davies et al. used intact sheep and it is possible that ovariectomized sheep are more sensible to the GH releasing effect of estrogen. They found, however, that die- 
thylstilbestrol like GH increased the blood levels of glucose and insulin and decreased the urea-nitrogen level.

The effect of estrogen on cholesterol metabolism was briefly summarized by Boyd (1963). He stated that in rabbit and women ovariectomy produces an increase in serum cholesterol of about $30-50 \%$ of the pretreatment level. In the present study serum cholesterol was lower in the ovariectomized sheep than in a group of intact sheep of the same age. The difference, however, was not statistically significant.

As seen from Table 1 a single injection of $2.5 \mathrm{mg}$ estradiol gave a biphasic cholesterol response. After $24 \mathrm{hrs}$. the level was decreased, but thereafter a steady increase occurred. Uchida et al. (1969) reported that estrogen possesses two opposite effects on serum cholesterol in the rat. They stated that small doses administered during long time increase the cholesterol level, while large doses cause a rather rapid decline. All their experiments were going on for several weeks. In the present study a single injection of a small dose changed serum cholesterol for several days. It is obvious that sheep and rat differ in cholesterol response to estrogen.

Recently Steinberg (1969) presented evidence that also estrogen-induced changes in serum cholesterol were pituitary dependent. It was found that hypophysectomy increased serum cholesterol in rats and that hypophysectomized rats were insensitive to the hypocholesterolemic effect of estrogen.

It thus seems possible that all the metabolic changes observed in the present study were mediated by the pituitary.

\section{REFERENCES}

Boyd, G. S.: Hormones and cholesterol metabolism. In The Control of Lipid Metabolism. ed. J. K. Grant, Academic Press, London and New York 1963.

Carlson, L. A., L. Levi \& L. Orö: Plasma lipids and urinary excretion of catecholamines in man during experimentally induced emotional stress and their modification by nicotinic acid. J. clin. Invest. 1968, 47, 1795-1805.

Davies, S. L., U. S. Garrigus \& F. C. Hinds: Metabolic effects of growth hormone and diethylstilbestrol in lambs. III. Metabolic effects of DES. J. Animal Sci. 1970, 30, 241-244.

Dole, V. P.: A relation between non-esterified fatty acid in plasma and the metabolism of glucose. J. clin. Invest. 1956, 35, 150 154. 
Frantz, A. G. \& M. T. Rabkin: Effects of estrogen and sex difference on secretion of human growth hormone. J. clin. Endocr. 1965, $25,1470-1480$.

Furman, R. H., R. P. Howard, L. N. Norcia \& E. C. Keaty: The influence of androgens, estrogens and related steroids on serum lipids and lipoproteins. Amer. J. Med. 1958, 24, 80-97.

Gilmour, K. E. \& K. W. McKerns: Insulin and estrogen regulation of lipid synthesis in adipose tissue. Biochim. biophys. Acta 1966, $116,220-228$.

Laron, Z. \& A. Kowadlo-Silbergeld: Fat mobilizing effect of estrogens. Acta endocr. (Kbh.) 1965, 48, 125-131.

Manns, J. G. \& J. M. Boda: Effects of ovine growth hormone and prolactin on blood glucose, serum insulin, plasma non-esterified fatty acids and amino nitrogen in sheep. Endocrinology 1965, $76,1109-1114$.

Preston, R. L. \& W. Burroughs: Stilbestrol responses in lambs fed rations differing in calorie to protein ratios. J. Animal Sci. 1958, $17,140-151$.

Radloff, H. D. \& L. H. Schultz: Hormonal regulation of plasma free fatty acid concentration in ruminants. J. Dairy Sci. 1966, 49, $971-975$.

Shroder, J. D. \& S. L. Hansard: Effects of dietary stilbestrol upon certain endocrine organs in lambs. J. Animal Sci. 1958, 17, $569-575$.

Steinberg, M.: Hypophyseal mediation of estrogen-induced hypocholesterolemia. In Drugs Affecting Lipid Metabolism. ed. W. L. Holmes, L. A. Carlson \& R. Paoletti. Plenum Press, New York 1969.

Trankle, A.: Plasma levels of growth hormone, insulin and plasma protein-bound iodine in finishing cattle. J. Animal Sci. 1970, 31, 389-393.

Uchida, K., M. Kadowaki, K. Miyata \& T. Miyake: Biphasic effect of estrogen on rat plasma cholesterol level and its interaction by androgen. Endocr. jap. 1969, 16, 211-214.

\section{SAMMENDRAG}

Effekten av estrogen och progesteron på blodglykos, NEFA och kolesterol hos ovariektomerade får.

Effekterna av estradiolbenzoat och progesteron på blodglykos, NEFA och kolesterol studerades hos ovariektomerade får. Intramuskulär injektion av $2,5 \mathrm{mg}$ estradiolbenzoat gav bifasiska förändringar av NEFA. Efter 2 timmar sjönk NEFA, men därefter iakttogs en kraftig stegring. Högsta värdena uppmättes efter 24 timmar. Blodglykosvärdena var signifikant förhöjda från 12 till 48 timmar efter injektionen. Serum kolesterol sjönk efter 24 timmar, men steg sedan kontinuerligt och var högst efter 120 timmar. Progesteron i samma do- 
sering orsakade inga förändringar av de studerade parametrarna. Simultan injektion av estradiolbenzoat och progesteron gav samma förändringar som enbart estradiolbenzoat.

Blodglykos och NEFA följdes under en brunstperiod hos en lakterande ko. Båda parametrarna ökade efter ovulationen.

Emedan NEFA var förhöjt under så lång tid efter injektionen av estradiolbenzoat diskuterades denna effekt mera ingående. Inget lipolytiskt hormon har rapporterats ha så långvarig effekt. Det är emellertid känt att estrogener höjer plasmakoncentrationen av $\mathrm{GH}$, och eftersom GH har en kraftigt lipolytisk effekt ansågs det troligt att de förhöjda NEFA-värdena kunde ha orsakats av ökad sekretion. Dessutom finns i litteraturen belägg för att även estrogenernas effekt på serum kolesterol är hypofysberoende. Det syntes därför rimligt att anta att alla de observerade metaboliska förändringarna av estradiolbenzoat medierades via hypofysen.

(Received June 7, 1971).

Reprints may be requested from: Jan Luthman, Department of Medicine II, Royal Veterinary College, S-10405 Stockholm 50, Sweden. 